\title{
Regional Head Election (Pilkada) Dispute Settlement in the Perspectives of Sociology of Islamic Law
}

\author{
M. Wagianto
}

\begin{abstract}
Regional Head Election (Pilkada) Dispute Settlement in the Perspectives of Sociology of Islamic Law. This article presents an alternative concept of resolving disputes over Regional Head Elections (Pilkada) from the perspectives of the sociology of Islamic Law. The aim is to find the possibility of obtaining better alternative dispute resolutions that meet the feelings of justice of the parties. Up to now, Pilkada dispute resolution always took the path of litigation (court), which ended in victory on the one side and defeat on the other side. Rarely, if ever, there is a dispute settlement that takes a non-litigation path to get a win-win solution. Even though there were no historical documents found in Islamic history on the Regional Head elections; But the absence of the document does not necessarily mean that Islam has no concept that can be used to solve humanitarian problems. As a religion characterized by rahmatan lil alamin (peace upon the world), Islam has a concept that can be applied to resolve disputes that refer to some principles originating from Syari'ah arguments, namely: al-Qur'an, al-Sunnah, Ijm $\vec{a}$ (agreement of the scholars), Qiyās (analogy), Maslahah Mursalah (benefit of society), and 'Urf (community tradition).
\end{abstract}

Keywords: settlement of election disputes, sociology of Islamic law, Pilkada

\begin{abstract}
Abstrak: Penyelesaian Sengketa Pilkada dalam Perspektif Sosiologi Hukum Islam. Artikel ini mengetengahkan suatu konsep alternatif penyelesaian sengketa Pemilihan Kepala Daerah (Pilkada) yang bersumber dari sosiologi Hukum Islam. Tujuannya untuk mencari kemungkinan memperoleh alternatif penyelesaian sengketa Pilkada yang lebih memenuhi perasaan keadilan para pihak. Selama ini, penyelesaian sengketa Pilkada selalu menempuh jalur litigasi (pengadilan), yang berakhir dengan kemenangan di satu pihak dan kekalahan di pihak lain. Jarang sekali, itupun jika pernah ada, penyelesaian sengketa yang menempuh jalur non litigasi untuk mendapatkan hasil yang dapat diterima para pihak (win-win solution). Bahwa kendatipun dalam sejarah Islam tidak ditemukan adanya dokumen historis tentang penomena pilkada, namun ketiadaan dokumen itu tidak serta merta berarti bahwa Islam sama sekali tidak memiliki konsep yang dapat digunakan untuk menyelesaikan problem kemanusiaan. Sebagai suatu agama yang berkarakter rahmatan lil 'alamin, Islam memiliki konsep yang dapat diterapkan untuk menyelesaikan sengketa yang merujuk sejumlah prinsip yang bersumber kepada dalil-dalil Syara', yang berupa al-Qur'an, al-Sunnah, Ijmä (kesepakatan para ulama'), Qiyās (analogy), Maslahah Mursalah (kemaslahatan masyarakat), dan 'Urf (tradisi masyarakat).
\end{abstract}

Kata Kunci: penyelesaian sengketa , sosiologi hukum Islam, Pilkada 


\section{Introduction}

Regional Head Elections (Pilkada) are part of the holding of general elections in Indonesia. According to Yusdianto, the elections have three important functions in the administration of the Regional Government, namely:

1. As a means to elect Regional Heads under the wishes of the local community so that the elected leader is expected to understand and realize the will of the community;

2. Through the elections it is hoped that the choice of the regional community is based on the mission, vision, program and the quality and integrity of the candidates for the Regional Head, which will determine the success of the administration of the region;

3. As a means of accountability as well as a means of political evaluation and control of a Regional Head and the political forces that support him. ${ }^{1}$

In the independence era of the Republic of Indonesia, since the Old Order until the Reform Era, the development of the general elections in Indonesia has experienced various dynamics including leaving various legal issues. Political dynamics that occur both before, during, and after the campaign period, are often the subject of arguments for parties who lose in the election to sue opponents, namely the winner of the election. It is at this point that disputes between contestants begin, which then ends in the Constitutional Court court forum.

In general, the main cause of disputes in the elections is the existence of fraud committed by one party, ranging from black campaigns to the use of political money. The fraud can also originate from the election organizers' partiality to one of the contestants so that it results in losses to the other contestants.

The cases as revealed above, almost always appear in every regional head election, both at the provincial level (governor) and at the regency/ municipality level (regents/mayors). In Lampung province, one concrete

${ }^{1}$ Yusdianto, 'Identifikasi Penyelenggaraan Pemilu Kepala Daerah (Pemilukada) Dan Mekanisme Penyelenggaraan', Jurnal Konstitusi, 2.2 (2010), p. 44. 
example of a local election dispute occurred in the 2018 governor election. At the democracy event, there were 3 pairs of candidates for governor (Cagub) and vice-governor candidates (Cawagub) who advanced as contestants namely: Cagub / Cawagub pair M. Ridho Ficardo-Bachtiar Basri, Cagub/Cawagub Couple Herman HN-Sutono and Cagub/Cawagub Couple Arinal Djunaidi-Chusnunia (Nunik).

Based on the results of a provisional calculation conducted by the Lampung KPU, the Cagub / Cawagub pair number 3, Arinal DjunaidiChusnunia, won the contestation after receiving 1,548,506 votes $(37.78 \%$ of the total votes). ${ }^{2}$ On the results of this calculation, the pairs of cagub/ cawagub numbered 1 and 2 refused because there had been a lot of fraud committed by candidate No.3, especially in the form of money politics. ${ }^{3}$ Although the objections of the two partners had been resolved through a hearing conducted by Bawaslu, the plaintiffs were still dissatisfied because it turned out that the Bawaslu's decision rejected their lawsuit. This rejection eventually led to dissatisfaction among the candidate pairs, including supporters, which led to the emergence of some demonstrations in several places, both those carried out by supporters who were defeated and who won.

Feeling dissatisfied with the Provincial Bawaslu's decision, the two defeated pairs of cagub and cawagub then proceeded to settle the Constitutional Court (MK) with demands to cancel the decision of the KPUD decision on the determination of the elected Governor and Deputy Governor as well as holding a repeat election. But finally, the Constitutional Court through the Decision read on August 13, 2018 rejected all election complaints and set the pair Arinal Junaidi and Nunik as winners in the elections in Lampung. ${ }^{4}$

2 'Raih 37,78\% Suara, Arinal-Nunik Menangi Pilgub Lampung' <https://news.detik.com/ berita/d-4104398/raih-3778-suara-arinal-nunik-menangi-pilgub-lampung>

3 'PDI-P Tuding Ada Politik Uang Yang Luar Biasa di Pilkada Lampung' < https://nasional. kompas.com/read/2018/07/02/21050081/pdi-p-tuding-ada-politik-uang-yang-luar-biasa-di-pilkadalampung>.

${ }^{4}$ 'MK Tolak Gugatan Sengketa Pilgub Lampung 2018, Arinal Segera Ditetapkan Sebagai Gubernur Terpilih - Tribun Lampung' <https://lampung.tribunnews.com/2018/08/10/mk-tolakgugatan-sengketa-pilgub-lampung-2018-arinal-segera-ditetapkan-sebagai-gubernur-terpilih> . 
The question arises: Why does every local election dispute resolution always take litigation? Is there no other method of resolution outside the existing mechanism that might bring more sense of justice/satisfaction to the parties? This article tries to examine a new perspective in the resolution of Pilkada disputes which is based on the concept of Islamic legal sociology through the Tahkîm (Arbitration) method. This author's thought was put forward as an alternative offer for dispute resolution through a non-litigation mechanism which has so far been seldom taken by the parties to the dispute. This is following the statement of Satjipto Rahardjo who proposed the need to change the ways of legal settlement through a legal and justice approach. ${ }^{5}$

\section{Pilkada in the Perspective of Islamic Law}

Although it differs greatly from what is now, the practice of elections to establish a leader is known in Islam. This happened in the Tsaqifah Hall of the Bani Sa'idah not long after the Prophet's death. At that moment, the leaders of the Ansar and Muhajirin groups met to discuss and determine who would be chosen as a leader to continue the struggle of the Prophet Muhammad. In that event, although preceded by fierce debate, the leaders of the Anshar and Muhajirin groups include 'Umar ibn al-Khaththab, Abû Ubaydah ibn Jarah, Bashir ibn Sa'ad, Acid ibn Khudayr and Salim, the liberated Abu Khudzayfah slaves. agreed to appoint Abu Bakr as a leader who would continue the position of the Prophet as the leader of the people. ${ }^{6}$ Their agreement was then followed by the bai'at (Oath of allegiance) made by the leaders and continued with the bai'at of all Muslims who were present at the election, or not.

As for the election of regional heads, it has never been practiced in Islamic history because all regional heads were not elected by the local people unless appointed directly by the caliph. Nevertheless, Election as one of the means of electing a leader is completely contrary to Islamic

${ }^{5}$ Satjipto Rahardjo, Wajah Hukum Di Era Reformasi, (Bandung: Citra Aditya Bhakti, 2000), p. 61.

${ }^{6}$ Munawir Sjadzali, Islam Dan Tata Negara, Ajaran, Sejarah Dan Pemikiran, (Jakarta: UI Press, 1993), p. 23. 
teachings. Even in Islam choosing a leader to be trusted to realize the benefits of his law is mandatory. This is according to the Word of God in Surat Al Baqarah verse 30 as follows:

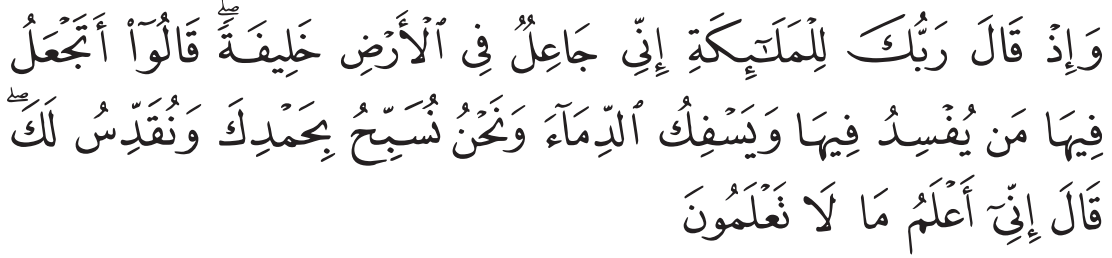

"Remember when your Lord said to the Angels:" Verily I will make you a caliph on the earth. " they said: "Why do you want to make (the caliph) on the earth a man who will harm him and shed blood, when We are ever praising you and purifying you?" God says: "Indeed I know what you do not know." (Al-Baqarah: 30$)^{7}$

The above verse is the basis for the general public to choose a leader, a figure that does no harm on the earth but is a blessing of alamin. The business of choosing a leader is given to mankind, while the good or bad of the leader is the only God who knows and determines.

One of the Islamic principles of power emphasizes that power is not a human right but a mandate of God. As Allah says in surah alAnfal verse 27:

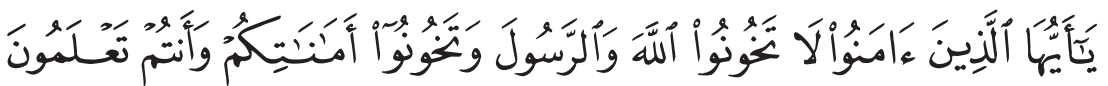

$O$ you who believe, do not trust in Allah and His Messenger and trust in the trust given to you, as you know it.

In surah an-Nisa 58 Allah says:

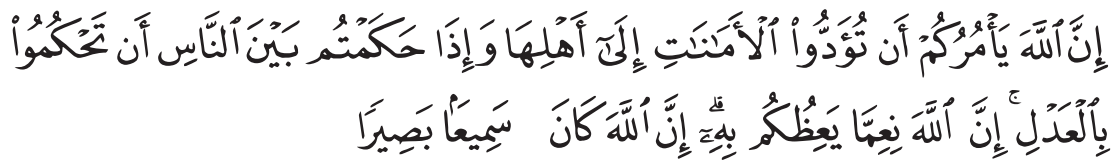

Verily, Allah commands you to deliver the mandate to those who have the right to receive it and to command you while establishing a law among men that you may justify. Verily, Allah gives you the best instruction. Verily, God is all-knowing, all-seeing.

${ }^{7}$ Departemen Agama, Al-Qur'an Dan Terjemahnya (Bandung: Diponegoro, 2005), p. 6. 
According to the word of Allah the power is a mandate and therefore in Islam no power can be absolute except for the power of God, the being who rules the whole universe. Islam does not recognize human sovereignty as embraced in Western democratic concepts; Islam simply recognizes human power as a trust, while the owners of both the trust and the absolute sovereign are still in the hands of Allah Almighty. This is where the fundamental difference between Islamic democracy and Western democracy lies. Democracy in Islam is a governed democracy and is subject to values that are following shariah principles. ${ }^{8}$

\section{The Provisions of the Regional Head Election (Pilkada) in Indonesia}

The Regional Head Election held in Indonesia is a peaceful mechanism for the change of power which is carried out periodically under the principles outlined in the constitution. An election is a political activity that is very important in the process of implementing power in a country that adheres to the principles of democracy. The principle of constitutional sovereignty of the people (democracy) is marked by the fact that every citizen has the right to take an active part in every process of state decision making. Article 18 paragraph (4) of the 1945 Constitution confirms that the Regional Head is democratically elected. The democratically elected formula was born from a long debate in the ad hoc committee I of the MPR Workers' Board in 2000 between opinions that wanted the Regional Head to be elected by the DPRD and other opinions that wanted to be directly elected by the people.

The development of regional head election mechanism in the country can be seen from the historical trajectory since the period of 1999 until now. The issuance of Law No. 22/1999 in place of Law No. 5/1974 was the initial milestone in the change in the nuances of politics in Indonesia, which was initially centralistic to decentralized and more open. Unfortunately, Law Number 22 the Year 1999 is

\footnotetext{
${ }^{8}$ Iskandar Syukur, Noor Sulastry Yurni Ahmad. 'The Indonesian Islam: Law and the Ideological Perspective'. al-'Adalah, 12.2 (2014), 235-248.

${ }^{9}$ Hamdan Zoelva, 'Problematika Penyelesaian Sengketa Hasil Pemilukada oleh Mahkamah Konstitusi', Jurnal Konstitusi, 10.3 (2016), Zoelva (p. 380) <https://doi.org/10.31078/jk\%x>.
} 
deemed to lack the spirit of reform and regional autonomy. so there is a desire to make revisions. To realize this desire, in 2004 a new legislation was issued namely Law Number 32 of 2004 Concerning Regional Heads that provided the opportunity to carry out direct Regional Head elections ${ }^{10}$ while establishing a new institution called the Election Commission as its organizing committee. The direct election of regional heads is regulated in Law no. 32 of 2004 in Article 56 jo. Article 119 and PP Number 6 of 2005 concerning procedures for the Election, Endorsement, Appointment, and Dismissal of Regional Heads and Deputy Regional Heads; As an implementation of this law, in 2005 in the District of Kutai Kertanegara, East Kalimantan, a local election was held which was the first direct election held in the history of government in Indonesia. After East Kalimantan, the implementation of post-conflict local elections in several regions in Indonesia was carried out based on the principles of Direct, General, Free, Confidential, Honest, Fair and Responsible.

In 2008, the Parliament passed Law No. 12 of 2008 concerning the Second Amendment to Law Number 32 of 2004 concerning Regional Governments which gave authority to the Constitutional Court (MK) to decide upon Disputes on the Results of Regional Head Elections. ${ }^{11}$ As a follow up to the mandate of the law, the Constitutional Court (MK) issued the Constitutional Court Regulation (PMK) No. PMK. 15 of 2008 concerning Guidelines for Procedure in Dispute over General Election Results (PHPU). In this regulation, it is stated that the authority of the Constitutional Court in deciding disputes over the results of regional elections covers the following matters:

${ }^{10}$ Mahi M. Hikmat, 'Pemetaan Masalah dan Solusi Konflik Lokal dalam Pilkada Langsung di Indonesia', MIMBAR : Jurnal Sosial dan Pembangunan, 30.1 (2014), 18-27 (p. 18) <https:// doi.org/10.29313/mimbar.v30i1.437>.direct election is not free from problems. To discover this fact, it is conducted research on Problem Mapping and Local conflict Solutions in Direct elections in Indonesia. By using descriptive qualitative method, it is concluded that: The main problem is the Direct Election of the general policy of the Government in the form of I"rules of play" and the adequacy of the implementation time to implement it.

${ }^{11}$ Iza Rumesten Rs, 'Dilema dan Akibat Hukum Putusan Mahkamah Konstitusi Mengenai Kewenangan Memutus Sengketa Pilkada’, Jurnal Konstitusi, 11.4 (2016), 693-713 (p. 694) $<$ https://doi.org/10.31078/jk\%x>. 
1. The results of vote counting determined by the provincial KPU / KIP or district/city KPU / KIP affect:

a. the determination of pairs of candidates who can participate in the second round of the election; or

b. the election of candidate pairs as Regional Head and Deputy Regional Head.

2. The election process that affects the vote acquisition of candidate pairs due to the systematic, structured, and massive election violations which are carried out before, during and after the voting. Election violations do not only occur during the voting, so the problems that occur must be traced from the events that occurred before the vote.

3. Violations of the provisions of the legislation in the election process that affect the vote acquisition and vote counting results can also be viewed as part of the election dispute, including the requirements of candidates for Regional Head or Deputy Regional Head.

In a further development, because the number of judges in the Constitutional Court was not proportional to the number of cases that came in ${ }^{12}$ coupled with the deadline for resolution of election cases that were limited for only 14 (fourteen) working days, resulting in the judges on duty became overwhelmed. Therefore, in 2013 the Constitutional Court issued Decision No. 97 / PUU-XI / 2013, which confirms that the election dispute is no longer the authority of the Court. The decision was annulled by the Government with the issuance of PERPU No. 1 year. 2014 regarding the election of Governors, Regents, and Mayors which precisely emphasized that the Constitutional Court still has the authority to handle regional election disputes in Indonesia. This PERPU was then approved by the House of Representatives through Law No. 1 of 2015 concerning the election of the Governor, Regent, Mayor ${ }^{13}$

${ }^{12}$ As a comparison, in 2009 the number of cases handled by this institution was 627 cases and 68 applications were granted.

${ }^{13}$ Ade Kosasih, 'Pelaksanaan Pilkada Secara Demokratis', FIAT JUSTITIA RUAT COELUM, 2008 <https://akosasih.wordpress.com/2008/09/25/pelaksanaan-pilkada-secara-demokratis/>. 
The following year, in the context of realizing the election of the Governor and Deputy Governor, the Regent and Deputy Regent, the Mayor and Deputy Mayor in a democratic manner, Law Number 1 the Year 2015 was revised by Law Number 8 Year 2015 ${ }^{14}$ and Law Number 10 the Year 2016 which continues to be in force today.

The purpose of the stipulation of regulations regarding the Election of Regional Heads as above in principle is to be a reference for implementing the tasks and functions of regional election organizers to realize the election of Regional Heads (Governor and Deputy Governor, Regent and Deputy Regent, Mayor and Deputy Mayor) in a democratic, honest, fair and responsible. Unfortunately, at the implementation level, the regulation was not implemented properly, ${ }^{15}$ which was marked by the emergence of many tensions or even social conflicts in almost all regions.

At least there are several causes related to the emergence of conflict as the impact of the implementation of the elections, namely: (1) There was a deviation in the implementation of the elections both by the organizers (KPU), the Supervisory Agency (Bawaslu) and from the contestants (candidates for Regional Head and Deputy Regional Head, Mayor and Deputy Mayor) or the Success Teams. (2) Black campaigns and negative propaganda both carried out in campaigns and through social media (online), brochures, pamphlets, banners, and other media; (2) The use of money politics that damages the foundations of democracy and the honesty of the election implementation; (3) The spirit to establish power which gave birth to political dynasties among former rulers, and so on.

The above violations give a negative picture of the implementation of the Regional Head Election in the Reformation era, damaging the image of the Implementers and the Regulatory Body as well as reducing the authority of those who are then elected. These things later became a source of conflict in the elections which not infrequently also affected the

${ }^{14}$ Muhammad Yasin al Arif, 'Politik Hukum Calon Tunggal Dalam Putusan Mahkamah Konstitusi dan Impliksasinya Terhadap Sistem Pilkada Serentak', Jurnal Yuridis, 3.2 (2017), 98-114 <https://doi.org/10.35586/.v3i2.182>.

${ }^{15}$ Dzunuwanus Ghulam Manar, 'Pilkada Langsung Dan Rekonstruksi Demokrasi Indonesia', FORUM, 41.1 (2014), 6-12 (p. 7). 
mobilization of the supporters. which is a problem and certainly answered through the sociology perspective of Islamic law, is an alternative solution and contribution to the development of law in the future.

\section{Election Dispute Resolution in Perspective of Islamic Law}

Although in practice, Indonesia still uses positive laws in force, such as election laws and other regulations, there is nothing wrong if policymakers look to other legal systems, both as a comparison and as inspiration to draw up local election law. better front.

There is various alternative dispute resolution in Islam known as Sulh (Peace), Tahkîm (Arbitration) and Wilayatul Qadha (Judgment). These types of dispute resolution methods are known in Islamic Law and have a legal basis in the Qur'an and Sunnah.

\section{A. Al-Sulh}

Al-Sulh which means peace or in terms means a type of contract or agreement to end a dispute. The legal basis of the method of resolving disputes with this model is Surat Al-Hujarat: 9 and Surah An-Nisa: 114 as follows:

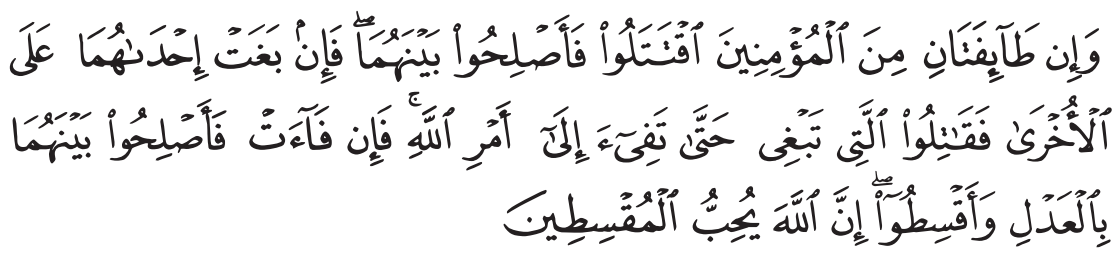

"If there are 2 (two) groups of believers who fight, make peace with them. But if one of the 2 (two) groups applies persecution against others, then fight those who persecute until they return to the command of Allah. When he returns, reconcile the two fairly and act righteously. Surely Allah (SWT) loves people who are just." (Al-Hujarat: 9)

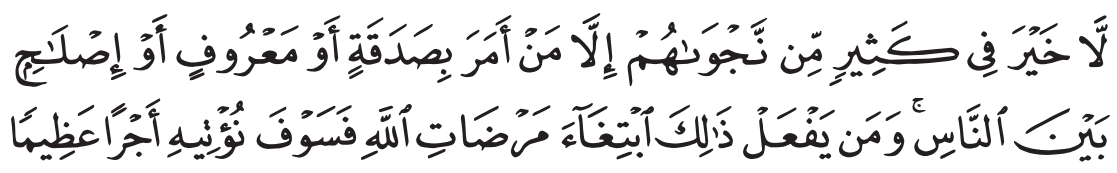

There is no good in most of their whispers, except the whispers of those who tell (humans) to give alms or do good or to reconcile among 
humans. Whoever does this for seeking the pleasure of Allah, we will give him a great reward later. (Surat an-Nisa (4): 114)

The method and mechanism of dispute resolution in this model are shaded by the values of universal human nature, namely peace-loving (Sulh), deliberation, kinship (ukhuwah) and loyal friends (takaluf).

In this mechanism, the disputing parties are given the freedom to take away settlement either by involving third parties or without involving third parties. If it involves a third party, then the third party is either a representation of each party and is assisted by a negotiator, or is a facilitator and mediator which does not favor anyone as in the practice of consultation or mediation. Whereas if it does not involve a third party, the parties resolve the dispute directly through a family meeting witnessed by another party such as a judge or other parties.

The Al-Sulh Method becomes the first and foremost alternative in dispute resolution according to Islamic Law. This is because: a). God's command in QS. Al-Hujurat verses 9 and 10 confirm that in the event of a dispute the parties are encouraged to take the path of peace. b). Going through the Sulh or ADR mechanism is far more effective and efficient than taking the arbitration mechanism or even the judicial process.

\section{B. Tahkîm (Arbitration)}

Tahkîm is derived from Arabic meaning to submit a decision to someone and accept the decision. According to the term, Tahkîm is two or more people who submit their case to someone to resolve their dispute and apply the syariah law 'for their dispute.

According to Al-Munjid's dictionary, Tahkîm is appointing someone as a referee or a peacemaker. While Salam Madkur stated in his book Al-Qadha Fil Islam that Tahkîm in terminologically means appointing one or more as referees or peacekeepers by two or more people in a dispute to settle the matter that they had set aside peacefully. ${ }^{16}$

${ }^{16}$ Zaenal Arifin, 'Arbitrase Dalam Perspektif Hukum Islam', Majalah Himmah, April 2006, pp. 67-68. 
In terms of Islamic jurisprudence, the meaning of Tahkim, as defined by Abu Al-Ainain Abdul Fatah Muhammad, is defined as the dependence of 2 (two) persons on a person to whom he or she decides to resolve their dispute. ${ }^{17}$ Abdul Karim Zaidan, that the Tahkîm is a rapture voluntarily from two people arguing over who they are trusted to resolve the dispute between them. ${ }^{18}$

Tahkim in the above understanding gives an understanding that the institution is not an official state institution, but as a private institution/ voluntary institution that is appointed and appointed directly by the parties to the dispute. The trust that is given to the judge seems very noble, but the burden of responsibility is quite heavy in resolving disputes faced.

The legal basis of the Tabkîm institution in Islamic sharia is the word of God in Q.S. al-Nisa (4): 35;

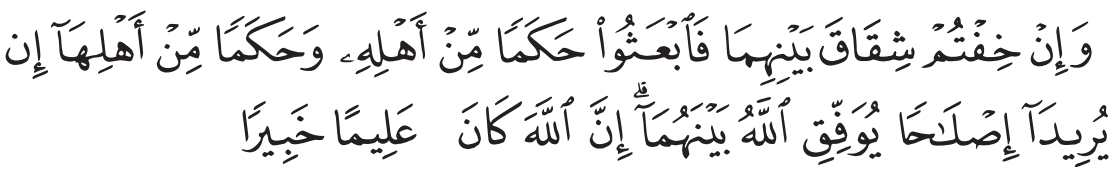

"And if you are worried that there will be a dispute between the two (husband and wife), then send an hakam (Arbitrator) from a female family and a male family. If the two hakam people make improvements (peace) surely Allah will give taufik to the husband and wife. Indeed, Allah Most High knows and knows." (An-Nisa': 35)

Narrated by An-Nasa'i that Abu Shuraih explained to the Messenger of Allah. that his people had a dispute in a case. Then they came to him, and he decided on their case. The decision was accepted by both parties. Hearing that, the Holy Prophet. said: How nice. Similarly, history states that the Messenger of Allah. has accepted the decision of Sa'ad bin Mu'az against the Banu Quraidah when the Jews agreed and were willing to accept the judgment from Sa'ad to them.

${ }^{17}$ A. Rahmat Rosyadi dan Ngatino, Arbitrase Perspektif Islam Dan Hukum Positif(Bandung: Citra Aditya Bhakti, 2002), p. 44.

${ }^{18}$ Oyo Sunaryo Mukhlas, Perkembangan Peradilan Islam : Dari Kahin Di Jazirah Arab Ke Peradilan Agama Di Indonesia. (Bogor: Ghalia Indonesia, 2011), p. 17. 
The concept of Islamic Law regarding Tabkîm/arbitration is not a ready-made concept in the form of legal rules but is still doctrinal in nature which can be developed as a basis for the validity of arbitration. That is because arbitration has never been discussed in Islamic fiqh, other than the concept of hakam in family matters.

Textually, Tahkîm in Islamic law is intended to resolve family (husband and wife) disputes. However, this method can also be used to resolve disputes in other fields such as politics based on the interpretation of analogies or Qiyas. Based on historical data, Tahkîm has been applied to end political disputes as happened in the Siffin war between the Caliph Ali bin Abi Talib's forces and Mu'awiyah's forces.

Arbitration or arbitration is one of the dispute resolution mechanisms based on mutual agreement with the principle of prioritizing peace or reconciliation. The Tahkîm Method can be used as an instrument of peace to resolve a dispute that arises in the present and the future. Although the Arbitrator's role in dispute resolution is the same as the role of a judge in a district court, which is to examine, hear and decide on a case/dispute submitted to him, the position of the judiciary in the court's heresy is lower than that of the Judiciary. Therefore, Abu Yusuf did not allow any conditions on Tahkîm. The law was given by Muhakkam only applies to people who accept the decision, while the decision from the judge must apply even if it is not accepted by the person concerned.

The fuqaha disagree on what areas of law can be solved by the Tahkîm method. Ibn Qudamah explained that the law prescribed by the judge applies in all cases, except in the case of marriage, li'an, qadzaf and qishash. Because these things can only be decided by the authorities. ${ }^{19}$ The followers of Ash Shaykh have two opinions on this matter. Ibn Farhun in Al Tabshirah says, that the verdict was in the realm of property, not in the criminal, Lian, qishash, qadzaf, divorce or descent. ${ }^{20}$

${ }^{19}$ T. M. Hasbi Ash-Shiddieqy, Peradilan Dan Hukum Acara Islam (Semarang: PT. Pustaka Rizki Putra, 2001), p. 83.”

${ }^{20}$ Abdul Azis Dahlan, Ensiklopedi Hukum Islam, Jilid 5 (Jakarta: PT. Ikhtiar Baru van Hoeve, 1996), p. 1752. 
The parties may waive the verdict before the judge issues the verdict. This judge is a muqallid who is obeyed by both parties. Therefore they can sue (fire) their muqallad, before they can break the law. But if the muqallad has already taken the decision, then the decision is valid and cannot be reversed. ${ }^{21}$

Some scholars argue that there is no need for both parties to enforce the law. If both have submitted their evidence to a magistrate, then one wants to withdraw the judgment before deciding the law, then the judge can continue to decide the law and the law.

According to Sahnun, each party can withdraw its decision, as long as there is no decision. This opinion is also conveyed by the opinion in the Malik Mazhab, which does not require continued consent from both parties to his administration before the law is enacted. ${ }^{22}$

The matter settled through Tahkîm is different from the settlement through Qadhi (judge). The verdict given by the judge must be carried out by the person concerned. If one judge gives the verdict, then the clerks go back and forth to the other judge, and the other judge gives a verdict that is contrary to the first one, so the verdict is valid. If the matter is referred to the judge, then the judge may justify the verdict if it is following his sect or may be contrary and even revoke the decision, contrary to the belief of his Mazhab.

\section{Wilayat Al-Qada}

Disputes or disputes that cannot be resolved either through a peace process (sulh) or arbitration (Tahkîm), then the final option is to pursue the third method of Wilayatul Qadha or through a legal process in court.

The legal basis of the Islamic qadha institution is described in the word of Allah Almighty, in the Qur'an Surah al-Maidah verse 49, which reads

\footnotetext{
${ }^{21}$ T. M. Hasbi Ash-Shiddieqy, p. 84.

${ }^{22}$ T. M. Hasbi Ash-Shiddieqy.
} 


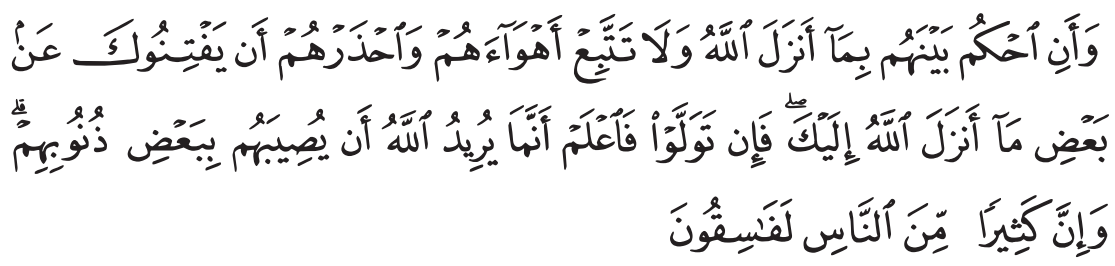

"And you must decide between them according to what Allah has revealed, and do not follow their desires. And beware of them, lest they deceive you in any of the things which Allah hath sent to you. If they turn away (from the law that God has revealed), then know that Allah is willing to suffer them for their sins. And really, most people are bad people." (Al-Maidah: 49).

In that verse, God commands man to resolve, decide, and correct things according to what $\mathrm{He}$ commands. If the person does not do what he is ordered to do, then he can fall into the category of disbelievers, tyrants, or vices.

If the judge has exercised his or her authority to exercise justice (after the mediation process has not been reached) the parties to the dispute must submit to and abide by the ongoing legal process. The judge in resolving the dispute should offer the option of reconciliation. This peace offer needs to be repeated, that is, at each beginning of the trial as long as the matter is not decided. The basis of the judge's obligation to reconcile the parties concerned is in line with the demands and demands of Islamic moral teaching. Islam has always asked to resolve any disputes and disputes through the ishlâh ( $f a$ aslikh û baina akhwaikum) approach. ${ }^{23}$

When peace is made an alternative and a model of the solution, there is no losing and winning effect, which can envy, envy, hatred, and hostility between them. All parties are the winning parties because they are decided by mutual agreement. Thus, the resolution of the dispute by peaceful means seems to be more friendly, which can calm and appease the parties. ${ }^{24}$

${ }^{23}$ Yahya Harahap, Kedudukan Kewenangan Dan Acara Peradilan Agama (Jakarta: Sinar Grafika, 2005), p. 65.

${ }^{24}$ Oyo Sunaryo Mukhlas, p. 65. 
Before the judge gives a verdict, the judge has the right to look at the previous decision. If the disputing party has made peace through the judiciary and obtained the verdict from a judge, if the judge agrees with the verdict then he is not allowed to revoke the verdict. However, if the judge disagrees with the verdict, the judge has the right to rescind it and issue a new ruling under his or her conviction. ${ }^{25}$

\section{Conclusion}

The election of Regional Head held in Indonesia is a mechanism of power shift that is expected to take place peacefully. However, the facts of the field indicate that peaceful elections are rare and that there are disputes among the contestants, either because of certain events that occurred before, during, or after the election. During this time, the resolution of the Election dispute has always been the path of litigation, which ends with victory in one division and defeat in the other. Rarely, if ever, does the dispute resolve a non-litigation path to win a win-win solution.

The future needs to be considered in a non-reckless Electoral Dispute Settlement procedure focusing only on the provisions of the positive law but also the remedies as contained in Islamic Law. Although Islamic law is not the cornerstone of Indonesia's resolution of election disputes in Indonesia, at least the principles and values contained in the provisions of the law can be a source of inspiration in shaping the patterns of election processes and mechanisms in the future.

\section{Bibliography}

Arif, Muhammad Yasin al, 'Politik Hukum Calon Tunggal dalam Putusan Mahkamah Konstitusi dan Impliksasinya Terhadap Sistem Pilkada Serentak', Jurnal Yuridis, 3.2 (2017), 98-114 <https://doi. org/10.35586/.v3i2.182>.

Arifin, Zaenal. 'Arbitrase dalam Perspektif Hukum Islam', Majalah Himmah, April 2006.

${ }^{25}$ Ahmad Mujahidin, Pembaharuan Hukum Acara Peradilan Agama (Bogor: Gha, 2012), p. 153. 
Ash-Shiddieqy, T. M. Hasbi. Peradilan dan Hukum Acara Islam. Semarang: PT. Pustaka Rizki Putra, 2001.

Dahlan, Abdul Azis. Ensiklopedi Hukum Islam, Jilid 5. Jakarta: PT. Ikhtiar Baru van Hoeve, 1996.

Departemen Agama, Al-Qur'an dan Terjemahnya. Bandung: Diponegoro, 2005.

Harahap, Yahya. Kedudukan Kewenangan dan Acara Peradilan Agama. Jakarta: Sinar Grafika, 2005.

Hikmat, Mahi M., 'Pemetaan Masalah dan Solusi Konflik Lokal dalam Pilkada Langsung di Indonesia', MIMBAR : Jurnal Sosial dan Pembangunan, 30.1 (2014), 18-27 <https://doi.org/10.29313/ mimbar.v30i1.437>.

Kosasih, Ade. 'Pelaksanaan Pilkada Secara Demokratis', FIAT JUSTITIA RUAT COELUM, 2008 <https://akosasih.wordpress.com/2008/09/25/ pelaksanaan-pilkada-secara-demokratis/>.

Manar, Dzunuwanus Ghulam, 'Pilkada Langsung dan Rekonstruksi Demokrasi Indonesia', FORUM, 41.1 (2014), 6-12.

'MK Tolak Gugatan Sengketa Pilgub Lampung 2018, Arinal Segera Ditetapkan Sebagai Gubernur Terpilih - Tribun Lampung' <https:// lampung.tribunnews.com/2018/08/10/mk-tolak-gugatan-sengketapilgub-lampung-2018-arinal-segera-ditetapkan-sebagai-gubernurterpilih>

Mujahidin, Ahmad. Pembaharuan Hukum Acara Peradilan Agama. Bogor: Gha, 2012.

Mukhlas, Oyo Sunaryo. Perkembangan Peradilan Islam : dari Kahin di Jazirah Arab Ke Peradilan Agama di Indonesia. Bogor: Ghalia Indonesia, 2011.

'PDI-P Tuding Ada Politik Uang Yang Luar Biasa di Pilkada Lampung' <https://nasional.kompas.com/read/2018/07/02/21050081/pdi-ptuding-ada-politik-uang-yang-luar-biasa-di-pilkada-lampung >.

'Raih 37,78\% Suara, Arinal-Nunik Menangi Pilgub Lampung' <https:// news.detik.com/berita/d-4104398/raih-3778-suara-arinal-nunikmenangi-pilgub-lampung>. 
Rs, Iza Rumesten, 'Dilema dan Akibat Hukum Putusan Mahkamah Konstitusi Mengenai Kewenangan Memutus Sengketa Pilkada', Jurnal Konstitusi, 11.4 (2016), 693-713 <https://doi.org/10.31078/jk\%x>.

Rahardjo, Satjipto. Wajah Hukum di Era Reformasi. Bandung: Citra Aditya Bhakti, 2000.

Rosyadi,A. Rahmat, dan Ngatino. Arbitrase Perspektif Islam dan Hukum Positif. Bandung: Citra Aditya Bhakti, 2002.

Sjadzali, Munawir. Islam dan Tata Negara, Ajaran, Sejarah dan Pemikiran, Jakarta: UI Press, 1993.

Syukur, Iskandar \& Noor Sulastry Yurni Ahmad. 'The Indonesian Islam: Law and the Ideological Perspective'. al-'Adalah, 12.2 (2014), 235-248. Yusdianto, 'Identifikasi Penyelenggaraan Pemilu Kepala Daerah (Pemilukada) dan Mekanisme Penyelenggaraan', Jurnal Konstitusi, 2.2 (2010).

Zoelva, Hamdan, 'Problematika Penyelesaian Sengketa Hasil Pemilukada oleh Mahkamah Konstitusi', Jurnal Konstitusi, 10.3 (2016), Zoelva $<$ https://doi.org/10.31078/jk\%x>. 